\title{
Tannery wastewater sediments produced by clinoptiolite/polyacrylamide-aided flocculation as a clay additive in brick making
}

\author{
K. Köseoglu ${ }^{1}$ • H. Cengizler ${ }^{2}$ L. İ. İsrail ${ }^{1} \cdot$ H. Polat $^{3}$
}

Received: 22 April 2017 /Revised: 31 May 2017 / Accepted: 12 June 2017 /Published online: 24 June 2017

(C) Australian Ceramic Society 2017

\begin{abstract}
Toxic tannery wastewater(s) (TWW) pose(s) a great risk to the environment. This study explores the potential of mitigating the harmful effects of TWW through sedimentation using clinoptiolite in the presence of various anionic, cationic and non-ionic flocculants with different molecular weights and charge densities followed by encapsulation in a brick structure for stability. Compressive strength (CS), size reduction after firing (SRAF), water absorption (WA) and colouring parameters of bricks were determined. X-Ray diffraction (XRD) and scanning electron microscopy (SEM)-energy dispersive X-ray (EDX) analyses were conducted on brick bodies. Kinetic leaching experiments were conducted for possible heavy metal release from the bricks. Bricks containing $10 \mathrm{wt} \%$ leather waste and $5 \mathrm{wt} \%$ clinoptiolite sintered at $800{ }^{\circ} \mathrm{C}$ instead of $920^{\circ} \mathrm{C}$ possessed similar properties to the standard brick (SB).
\end{abstract}

Keywords Clinoptiolite $\cdot$ Sedimentation $\cdot$ Polyacrylamide . Leather residues $\cdot$ Brick

\section{Introduction}

Raw hide or skin is the raw material of leather industry from which leather is produced. Hides are subjected to a number of

Original article revised.

H. Cengizler

hakan.cengizler@cbu.edu.tr

Ege University, Ege Vocational School, 35040 Izmir, Turkey

2 Celal Bayar University, Turgutlu Vocational School, 45410 Turgutlu, Turkey

3 Department of Chemistry, Izmir Institute of Technology, 35430 İzmir, Turkey chemical and mechanical treatments. These treatments which turn the hides into a physically and chemically more durable products and less susceptible to decomposition usually involve three distinct phases: the preparation in the beamhouse, tanning in the tanyard and finishing which includes dyeing and surface treatment. Leather tanning is the key process of converting raw hides or skins into leather. In this process, animal hides and skins are treated to remove hair and nonstructured proteins and fats, leaving an essentially pure collagen matrix. The hides are then preserved by impregnation with tanning agents [1]. The tanning process is essentially the reaction of collagen fibres in the hide with a wide range of mineral-tanning chemicals [2]. The most common tanning agents are chromium salts (trivalent chromium) ( $\sim 90 \%$ of the worldwide usage) and vegetable tannins [2-8]. Through the tanning process, the leather becomes stable against sweat or moisture, heat, microbial or enzymatic degradation, thermomechanical stress, etc. $[3,9,10]$.

Tanneries generate large amounts of liquid and solid wastes [11] which contain high contents of dissolved and suspended organic and inorganic solids giving rise to high oxygen demand and potentially toxic metal salts and chromium metal ions $[3,12,13]$. The unpleasant odour emanating from the decomposition of proteinous waste material and the presence of sulphide, ammonia and other volatile organic compounds are also associated with tanning activities. Therefore, tannery waste is a toxic material which should be correctly treated and disposed of not to cause any adverse effect on the surrounding land, water and the local flora and fauna [3, 13-16]. Although various treatment techniques such as coagulation-flocculation-sedimentation, ion exchange, adsorption, chemical precipitation and membrane filtration can be employed to remove heavy metals from contaminated wastewaters, they have their inherent advantages and limitations in application [17-23]. 


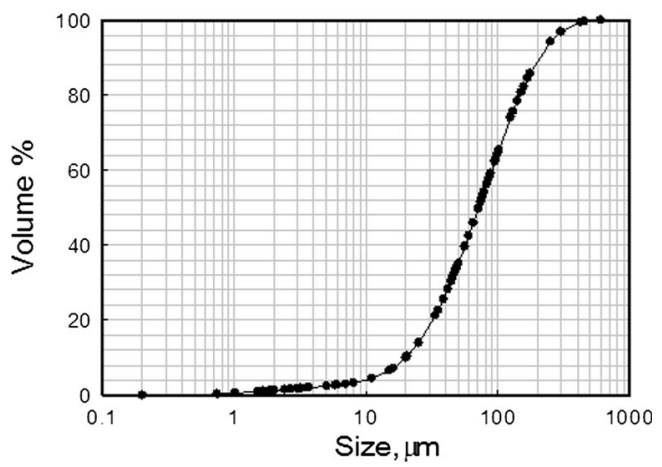

Fig. 1 The size distribution of clinoptiolite used in this study

Coagulation-flocculation-sedimentation method where metals salts are added for the purpose is commonly used to remove pollutants in particulate form in the primary step of the wastewater treatment. The studies on the use of alum and ferric chloride as coagulants for toxic tannery waste water (TWW) reported that ferric chloride produced better results than aluminium sulphate [21, 22]. Although alum has been probably the most widely used coagulant for treating wastewaters, it tends to generate less cake volume than iron-based coagulants. Nevertheless, it was also reported that metal salts produced porous, less compact sludge, which was difficult to dewater [20]. These sludges forming flocs with a threedimensional network were a two-phase mixture of solids and water. Their water contents before and after thickening were high varying between 99 and 95\% [21]. Coagulation-flocculation-sedimentation of TWW using combination of alum with cationic and anionic polymers as coagulant were also
Table 2 Chemical analysis of TWW

\begin{tabular}{ll}
\hline Elements & Concentration $(\mathrm{mg} / \mathrm{L})$ \\
\hline $\mathrm{Ca}$ & 622 \\
$\mathrm{~K}$ & 4935.3 \\
$\mathrm{Cu}$ & 1 \\
$\mathrm{Mn}$ & 0.04 \\
$\mathrm{~Pb}$ & 0.2 \\
$\mathrm{Al}$ & 9.5 \\
$\mathrm{Cr}$ & 30.7 \\
$\mathrm{Fe}$ & 1.6 \\
$\mathrm{Cd}$ & - \\
$\mathrm{Ni}$ & - \\
$\mathrm{Zn}$ & - \\
$\mathrm{Co}$ & - \\
$\mathrm{Hg}$ & - \\
\hline
\end{tabular}

studied [20]. It was reported that the combination of alum with cationic/anionic polymer resulted in better results. The comparison revealed that the use of coagulant aid reduced sludge volume by $60-70 \%$ and cost of chemicals by $50 \%$ for comparable removal efficiencies. So, using anionic polymers in combination with metal salts results in some advantages such as less sludge volumes and larger and compact flocs with greater settling rates leading to higher surface overflow rates for thickeners. Furthermore, the sludge contains much less water and is easy to dewater [20-22]. The coagulation-flocculation of oil and suspended solids in heavy oil wastewater by poly-zinc silicate and anionic polyacrylamide was investigated to reduce oil and suspended solid concentration. The

Table 1 Chemical analysis of clinoptiolite

\begin{tabular}{lclllc}
\hline Composition & Concentration $(\%)$ & Composition & Concentration $(\mathrm{mg} / \mathrm{L})$ & Composition & Concentration (mg/L) \\
\hline $\mathrm{SiO}_{2}$ & 67.3 & $\mathrm{Ba}$ & 120 & $\mathrm{Sr}$ & 338 \\
$\mathrm{Al}_{2} \mathrm{O}_{3}$ & 10.6 & $\mathrm{Ce}$ & 39.1 & $\mathrm{Ta}$ & 1.3 \\
$\mathrm{Fe}_{2} \mathrm{O}_{3}$ & 1.4 & $\mathrm{Cr}$ & 10 & $\mathrm{~Tb}$ & 0.66 \\
$\mathrm{CaO}$ & 2.52 & $\mathrm{Cs}$ & 29.4 & $\mathrm{Th}$ & 29.1 \\
$\mathrm{MgO}$ & 0.92 & $\mathrm{Dy}$ & 3.67 & $\mathrm{Tl}$ & $<0.5$ \\
$\mathrm{Na}_{2} \mathrm{O}$ & 0.29 & $\mathrm{Er}$ & 2.2 & $\mathrm{Tm}$ & 0.32 \\
$\mathrm{~K}_{2} \mathrm{O}$ & 3.83 & $\mathrm{Eu}$ & $\mathrm{U}$ & 7.39 \\
$\mathrm{C}$ & 0.29 & $\mathrm{Ga}$ & $\mathrm{V}$ & 17 \\
$\mathrm{Cr}_{2} \mathrm{O}_{3}$ & $<0.01$ & $\mathrm{Gd}$ & 13.3 & $\mathrm{Yb}$ & 2.26 \\
$\mathrm{TiO}_{2}$ & 0.09 & $\mathrm{Hf}$ & 3.83 & $\mathrm{Zr}$ & 73 \\
$\mathrm{MnO}$ & 0.04 & $\mathrm{Ho}$ & 3 & $\mathrm{As}$ & 20.2 \\
$\mathrm{P}_{2} \mathrm{O}_{5}$ & $<0.01$ & $\mathrm{La}$ & 0.74 & $\mathrm{Bi}$ & 0.43 \\
$\mathrm{SrO}$ & 0.04 & $\mathrm{Nd}$ & 18.9 & $\mathrm{Hg}$ & $<0.005$ \\
$\mathrm{BaO}$ & 0.01 & $\mathrm{Pr}$ & 16.7 & $\mathrm{Sb}$ & 0.58 \\
$\mathrm{~S}$ & 0.07 & $\mathrm{Rb}$ & 4.69 & $\mathrm{Se}$ & 0.5 \\
$\mathrm{LOI}$ & 11.1 & $\mathrm{Sm}$ & 204 & $\mathrm{Te}$ & 0.01 \\
\hline
\end{tabular}

${ }^{\mathrm{a}}$ Loss of ignition 
Table 3 Technical information of polymers

\begin{tabular}{llll}
\hline Technical name & $\begin{array}{c}\text { Relative molecular } \\
\text { mass }\left(\times 10^{6} \mathrm{~g} / \mathrm{mol}\right)\end{array}$ & Water content $(\% \mathrm{wt})$ & Ionization degree \\
\hline K 6645 & $6-8$ & $4-8$ & High cationic \\
A 4032 & $11-13$ & $4-10$ & Low anionic \\
A 4041 & $14-16$ & $4-10$ & Medium anionic \\
A 4045 & $15-17$ & $4-10$ & High anionic \\
A 4046 & $16-18$ & $4-10$ & High anionic \\
N 134 & $8-10$ & Undefined & Medium non-ionic \\
\hline
\end{tabular}

flocs morphology proved that poly-zinc silicate with anionic polyacrylamide formed the firm and tight flocs and could settle rapidly [22]. Although, coagulation-flocculation-sedimentation method for primary treatment of wastewater laden with heavy metals has advantages, this method involves high operational cost due to chemical consumption and increased sludge volume generation [23]. Furthermore, the toxic sludge must be somehow converted into a stable and safe product to prevent heavy metals from leaching into the environment.

Ion-exchange processes are widely used to remove heavy metals from wastewater due to their many advantages including high treatment capacity, high removal efficiency and fast kinetics. However, exhausted ion-exchange resins must be regenerated by chemical reagents leading to serious secondary pollution issues. Besides, they are expensive, especially when treating a large amount of wastewater containing heavy metal in low concentration, so they cannot be used at large scale [23]. Similarly, chemical precipitation is not effective at low metal contents and membrane separation due to large volumes.

Adsorption by zeolite minerals is one of the easiest, safest and most cost effective method for the removal of metals from aqueous solutions [24, 25]. Zeolites are naturally occurring micro-porous aluminium silicate minerals [26-30], and their exchangeable ions are relatively harmless. Among them, clinoptiolite is the most important zeolite type due to its excellent cation exchange properties, stability up to $700{ }^{\circ} \mathrm{C}$ temperature and dehydration [26, 27]. It has a high content of silica, and the most common balancing cations are $\mathrm{Na}^{+}, \mathrm{K}^{+}$, $\mathrm{Ca}^{2+}$ and $\mathrm{Mg}^{2+}$. In a number of studies, it has been demonstrated that zeolites hold great potential for removal of cationic

Table 4 Composition of SB body

\begin{tabular}{lc}
\hline Components & Percent \\
\hline $\mathrm{SiO}_{2}$ & 63.1 \\
$\mathrm{Al}_{2} \mathrm{O}_{3}$ & 16.4 \\
$\mathrm{Fe}_{2} \mathrm{O}_{3}$ & 5.9 \\
$\mathrm{CaO}$ & 5.6 \\
$\mathrm{MgO}$ & 2.3 \\
$\mathrm{~K}_{2} \mathrm{O}$ & 2.0 \\
$\mathrm{Na}_{2} \mathrm{O}$ & 0.5 \\
$\mathrm{LOI}$ & 4.2 \\
\hline
\end{tabular}

heavy metal ions from industrial wastewater under different experimental conditions [31-36]. However, to the best of our knowledge, comparative studies using the combinations of zeolites and very small quantities of polymeric coagulants to aid coagulation in the treatment of TWW have been scarce.

Therefore, in this study, clinoptiolite alone and together with anionic/cationic/non-ionic polymeric coagulants were used for the primary treatment of TWW by sedimentation. The purpose of the study can be summarized as to:

i) Use cheap and largely available clinoptiolite as the coagulant, instead of conventional coagulants such as metal salts, together with starving quantities of cationic, anionic and non-ionic polymers as coagulant aid

ii) Encapsulate and stabilize the harmful sediments generated in a brick structure which would otherwise pose risk to the environment upon disposal

iii) Reduce the amount of valuable clay raw material in the brick manufacturing process by replacing it with the sediment and alleviate the impact of mining activities on the environment

iv) Manufacture bricks which would satisfy the related brick standards

\section{Materials and methods}

\section{Materials}

Clinoptiolite sample was obtained from Enli Mining Enterprise (Manisa-Gördes /Turkey) with particle size distribution of $81 \%$ passing $150 \mu \mathrm{m}$ (Fig. 1) and specific surface area of 52-53 $\mathrm{m}^{2} / \mathrm{g}$ (BET, Micromeritics Gemini V). The TWW sample was provided by a leather factory (Kula-Manisa/Turkey). The analysis of the clinoptilolite (Table 1) and the atomic

Table 5 Recipe of brick bodies

\begin{tabular}{lrrrrrr}
\hline Wt\% & 100 & 99 & 97 & 95 & 93 & 90 \\
Clinoptiolite (\%) & - & 1 & 3 & 5 & 7 & 10 \\
\hline
\end{tabular}



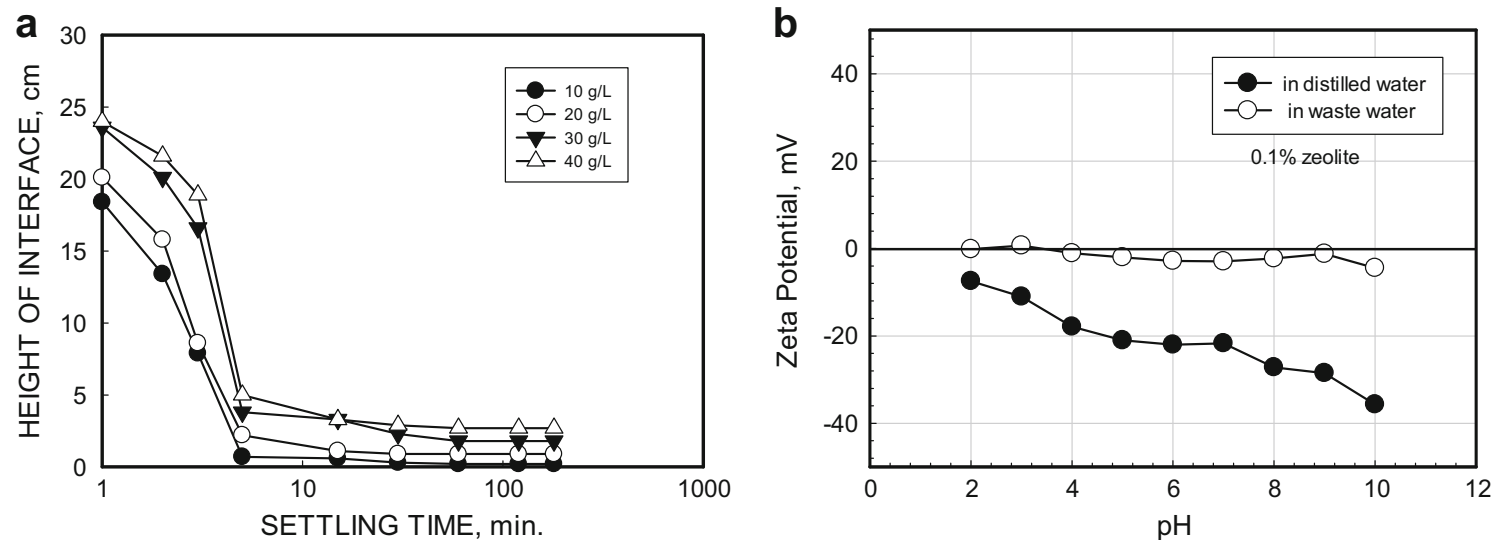

Fig. 2 a Height of solid-liquid interface with the settling time $(\mathrm{pH}=9.5$, mixing rate $=200 \mathrm{rev} / \mathrm{min})$. b Zeta potential of zeolite

absorption analysis of the TWW (Table 2) were carried out by the ALS Minerals Laboratory Services Ltd. and Ege University, The Department of Leather Engineering (Izmir, Turkey), respectively. Four different types of anionic (A 4032, A 4041, A 4045, A 4046), one cationic (K 6645) and one non-ionic (N 134) polyacrylamide/polyacrylamide (PAM) surfactants were used as flocculants (Table 3). All the surfactants were provided by Sigma-Aldrich. The SB clay was provided by Altın Kiremit brick factory (Menemen-Izmir/ Turkey). The XRF analysis of SB clay given in Table 4 was carried out at the quality control department of Ege Seramik Factory (İzmir, Turkey).

\section{Methods}

\section{Sedimentation experiments}

The suspensions with $10,20,30$ and $40 \mathrm{~g} / \mathrm{L}$ clinoptiolite content were prepared in tap water including $100 \mathrm{~cm}^{3}$ of TWW in a total volume of $500 \mathrm{~cm}^{3}$. The suspension was stirred for $1 \mathrm{~h}$ with a magnetic stirrer and poured into a graduated cylinder with a $5 \mathrm{~cm}$ inner diameter and was left to free settling. The variation in the height of the solid-liquid interface with time was determined. The final volume where the height of the solid-liquid interface remained constant was recorded as the final sediment volume (FSV). These experiments were conducted at various mixing and $\mathrm{pH}$ conditions. The $\mathrm{pH}$ of the TWW tap water system was adjusted to various values using $0.1 \mathrm{M} \mathrm{HCl}$ and $0.1 \mathrm{M} \mathrm{NaOH}$ solutions. After the optimal concentration of clinoptiolite for settling was determined, the solutions containing optimal concentration of clinoptiolite with various concentrations of PAM surfactants (20$1000 \mathrm{mg} / \mathrm{L}$ ) were prepared and flocculation experiments were carried out with the same procedure explained above. However, this time, specific polymer solutions prepared were used instead of tap water to assist settling.

\section{Turbidity measurements}

Turbidity is a measure of light transmittance of water containing suspended solid particles and often used to measure the performance of sedimentation. A Scientific Micro TPW model Turbidimeter was used for suspension with optimal clinoptiolite concentration and for suspensions containing
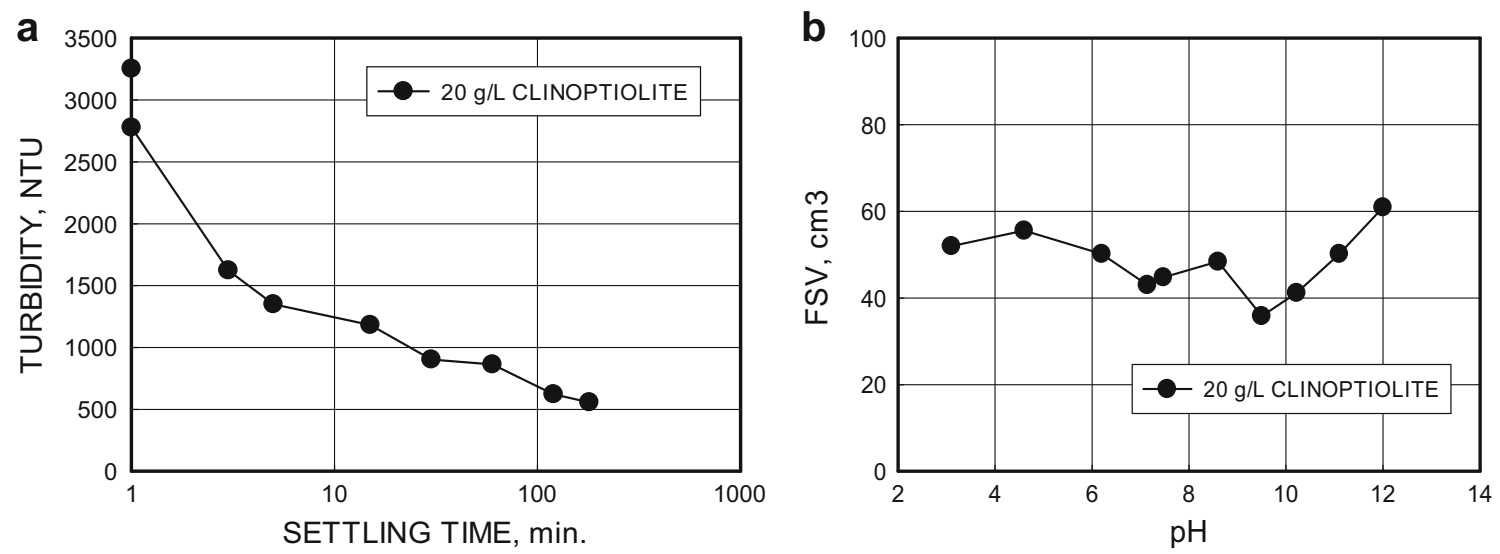

Fig. 3 a Turbidity measurements of supernatant after settling $(\mathrm{pH}=9.5)$. b Variation in the FSV with $\mathrm{pH}(20 \mathrm{~g} / \mathrm{L} \mathrm{C}$ content, $100 \mathrm{rev} / \mathrm{min}$ mixing rate, $1 \mathrm{~h}$ sedimentation time) 

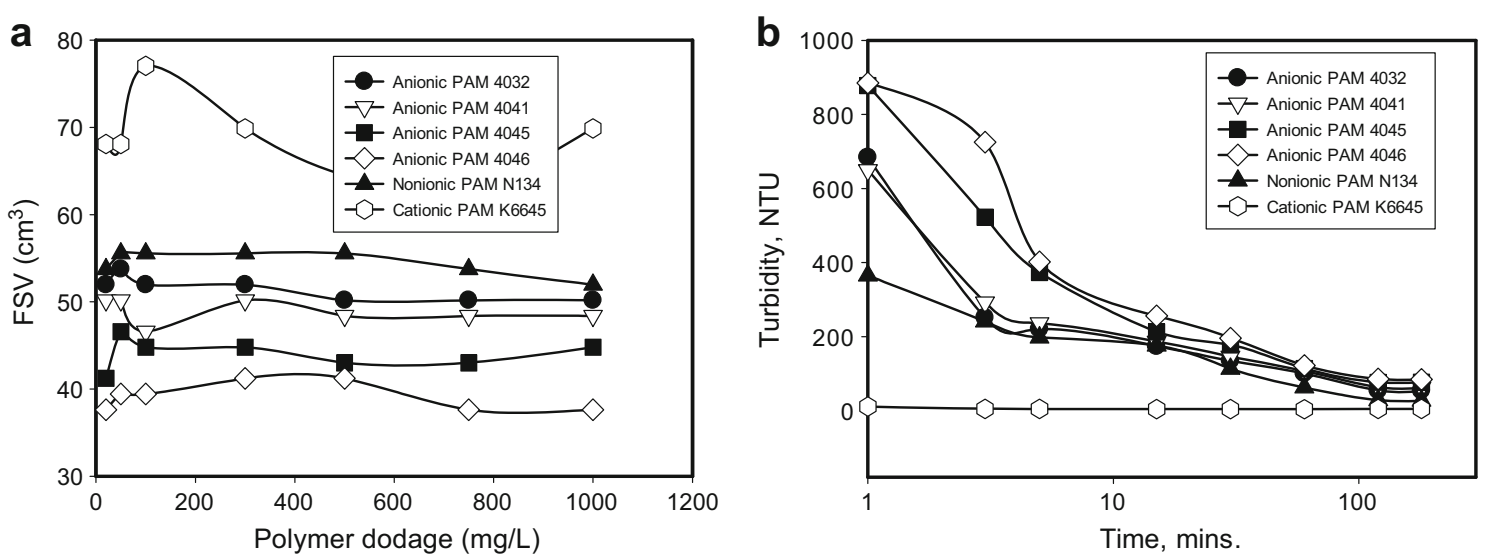

Fig. 4 a Variation in the FSV with PAM flocculation ( $20 \mathrm{~g} / \mathrm{L}$ Clinoptiolite, $\mathrm{pH}=9.5,100 \mathrm{rev} / \mathrm{min}$ mixing rate, $1 \mathrm{~h}$ sedimentation time). b Turbidity measurements in the presence of flocculants $(20 \mathrm{~g} / \mathrm{L}$ Clinoptiolite, $\mathrm{pH} .=9.5)$

optimal amount of clinoptiolite and various concentrations of polymeric flocculants mentioned above. For this purpose, $10 \mathrm{~mL}$ sample was taken from the supernatant and the variation in turbidity with settling time was determined.

\section{Production of bricks}

The SB were crushed down to $-4 \mathrm{~mm}$ using a laboratory jaw crusher before mixing with solid residue of TWW. The sediment produced from TWW, which contained $1.32 \%$ (by weight) of solid particles, was de-moisturized at $110{ }^{\circ} \mathrm{C}$ for $2 \mathrm{~h}$ in a laboratory drying oven (Heraus model). After drying, SB body was moisturized with $6 \mathrm{wt} \%$ water and mixed with various amounts of solid residue as seen in Table 5 .

The experimental mixtures of $70 \mathrm{~g}$ each were placed into a steel die with the dimensions of $5 \times 10 \times 1 \mathrm{~cm}$ and uniaxially pressed with the aid of a hydraulic press (SACMI 470, PIL type) under the pressure of $27 \mathrm{MPa}$ and dried at $110^{\circ} \mathrm{C}$ for an hour. These pressed samples were fired at 800, 850, 900 and $920{ }^{\circ} \mathrm{C}$ for $2 \mathrm{~h}$ in a laboratory electrical muffle furnace

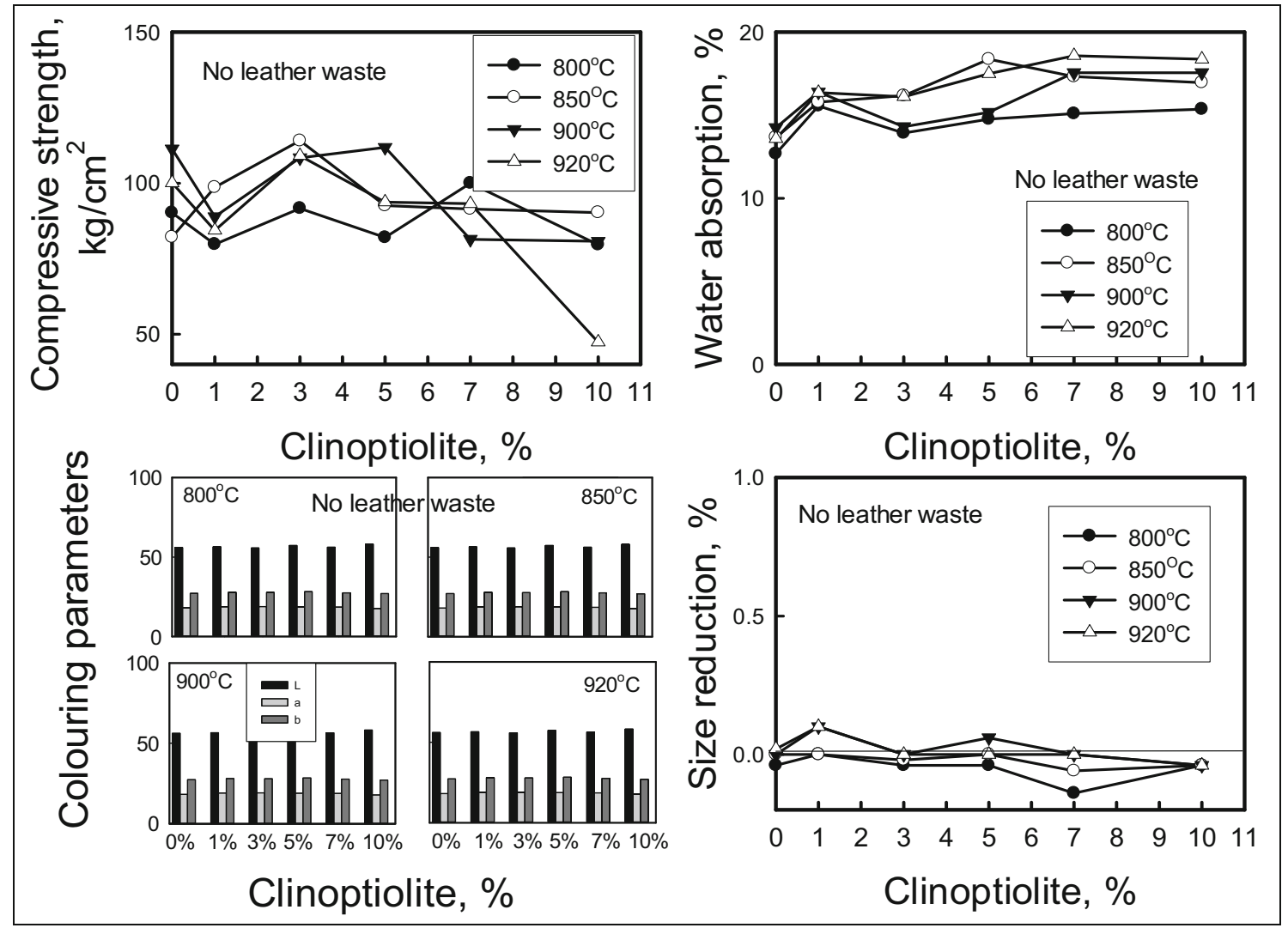

Fig. 5 Testing the properties of Type A bricks 


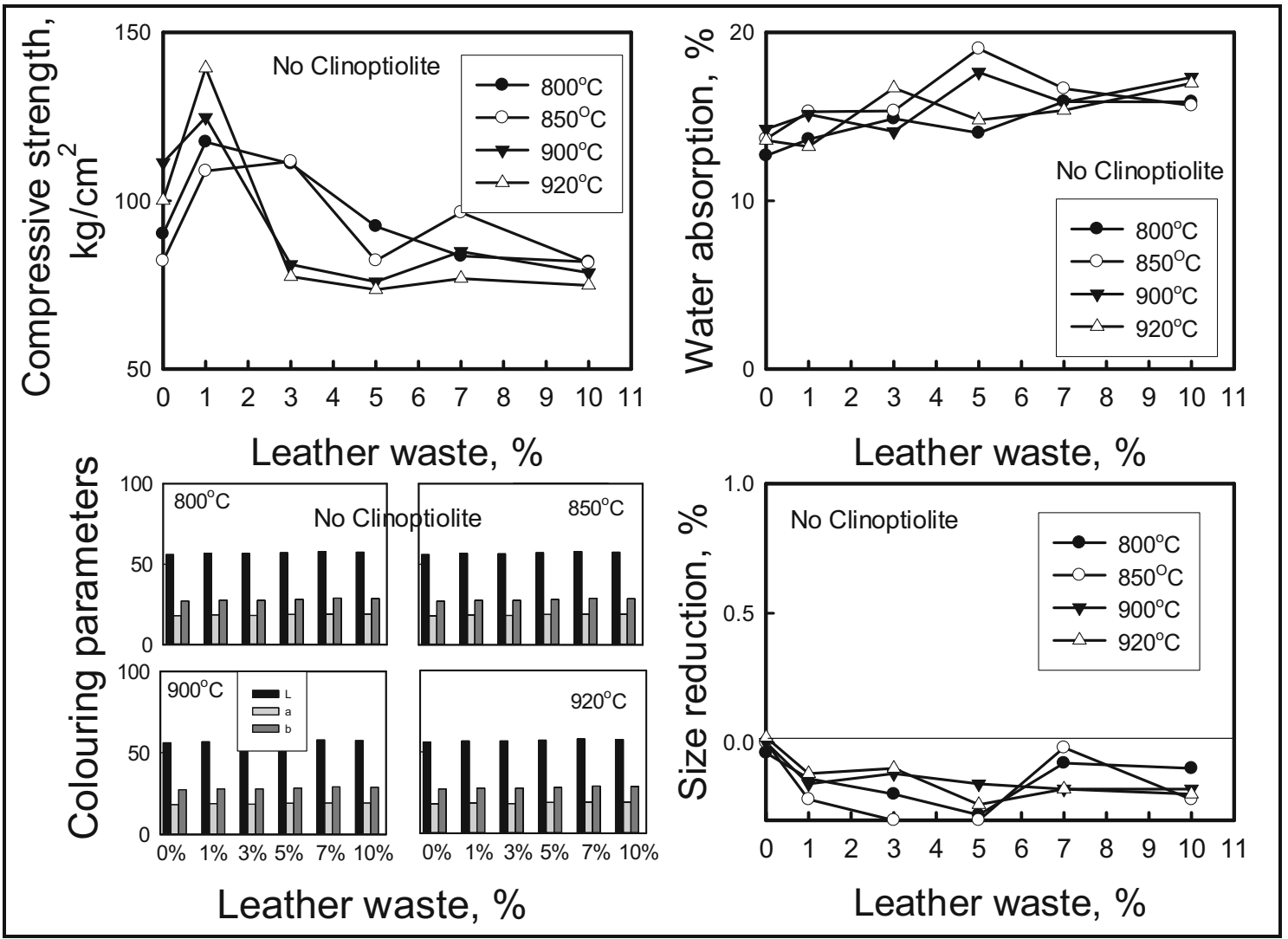

Fig. 6 Testing the properties of Type B bricks

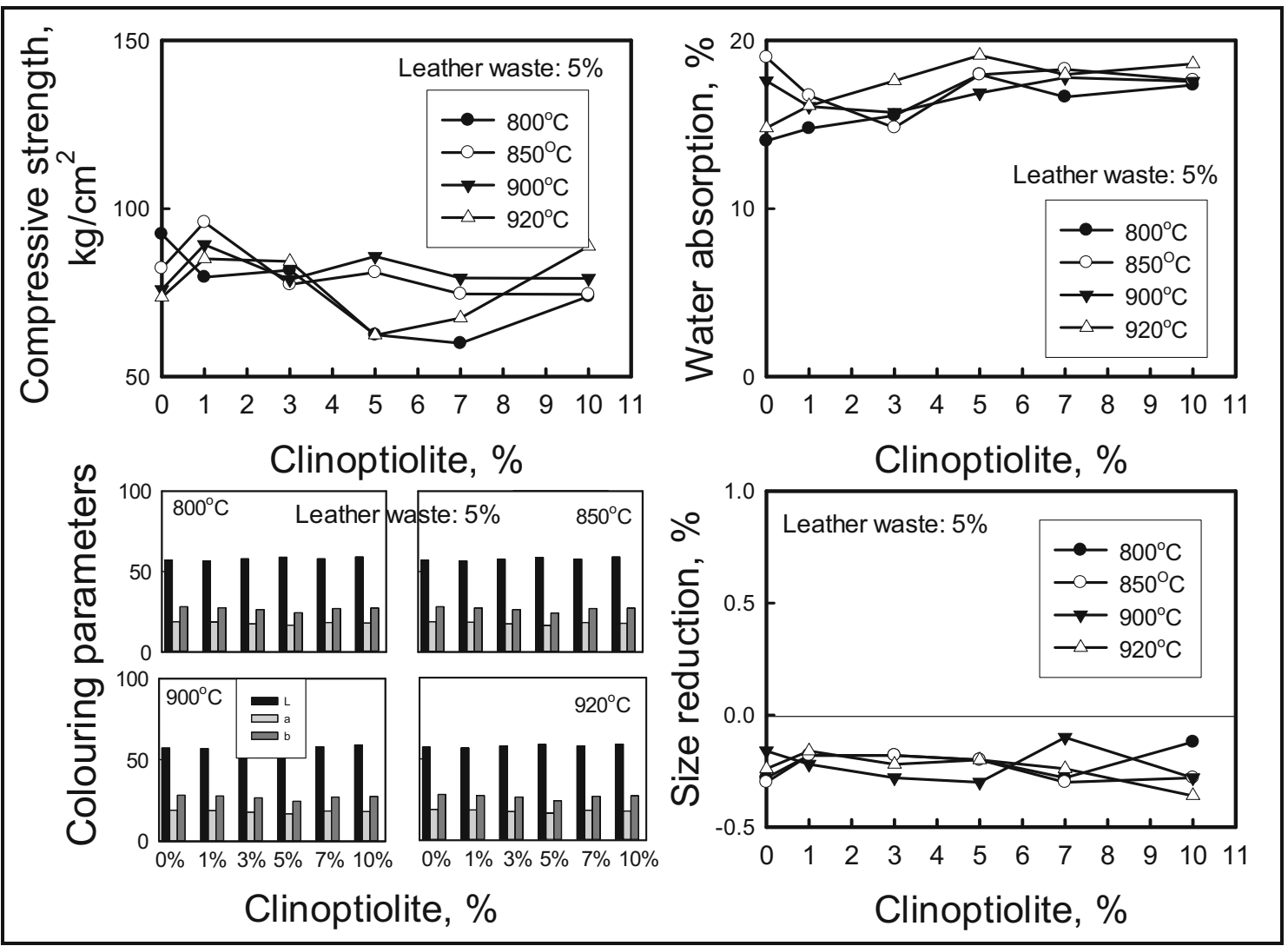

Fig. 7 Testing the properties of Type $\mathrm{C}$ bricks 


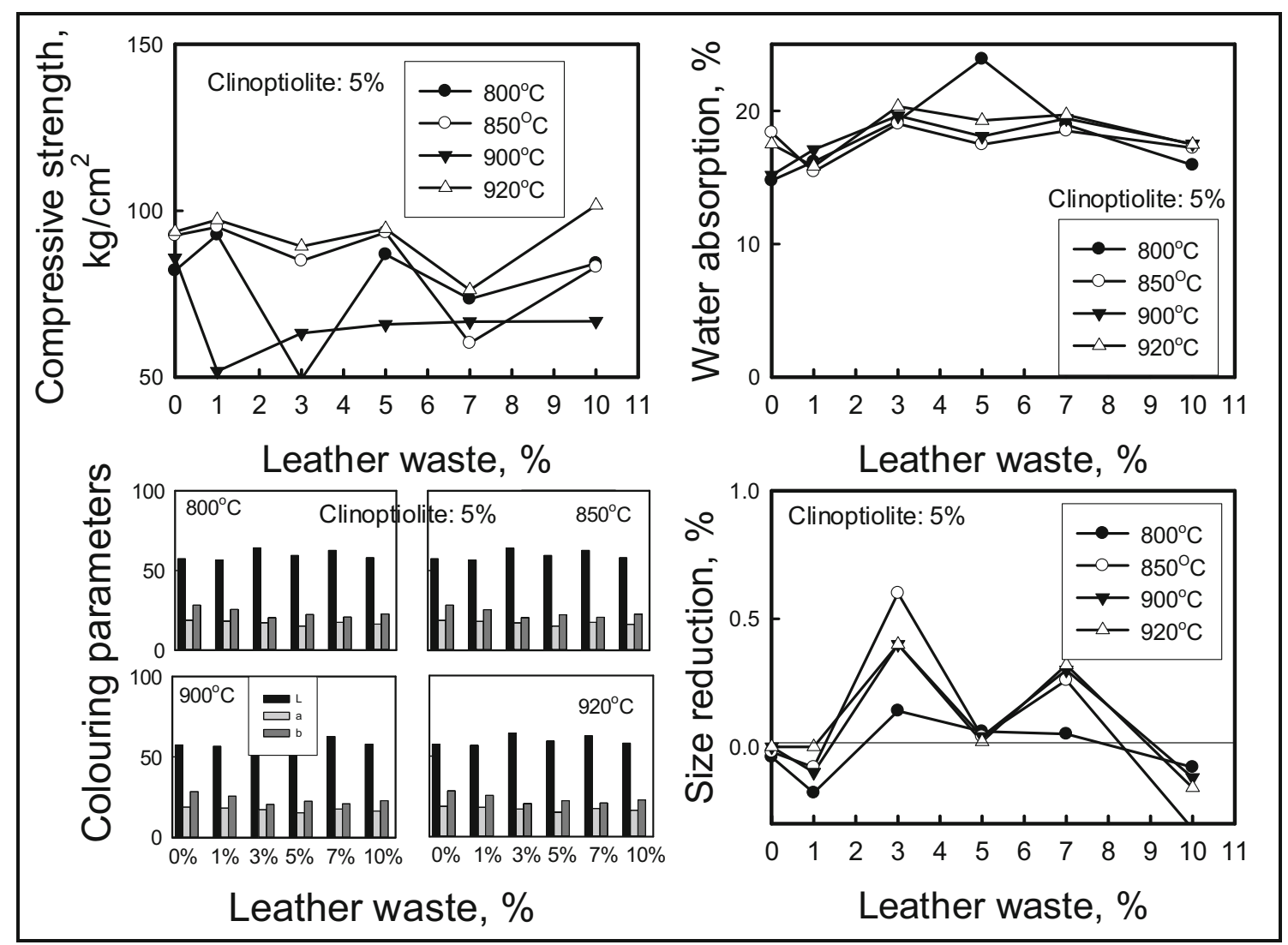

Fig. 8 Testing the properties of Type D bricks

(Nabertherm G100/9) with a dwelling time of $40 \mathrm{~min}$ at the maximum temperature. The fired brick samples were allowed to cool down to the room temperature, and their physicomechanical properties such as SRAF, CS and WA were determined according to TSE 705 [37], TSE 4790 [38] and Turkish standards in accord with ASTM and ASTM C67-92a [39], respectively. Three bricks were prepared and fired for each test condition and the average values of SRAF, CS and WA were obtained. CS tests were carried out on a Gabrielli Crometro CR4-A4-B4 hydraulic press.

\section{SEM-EDX and XRD analyses}

Qualitative determination of major crystalline phases present in the fired SB and experimental bricks was conducted by XRD on powdered samples using a Rigaku Miniflex II XRay powder diffractometer with Ni-filtered $\mathrm{Cu} \mathrm{K} \alpha$ $(\lambda=1.54 \AA)$ radiation in the $5-80^{\circ} 2 \theta$ range at $30 \mathrm{kVand}$ $15 \mathrm{~mA}$. SEM, using an accelerating voltage of 10 and
$20 \mathrm{kV}$, attached with a directional backscattering detector was conducted on a JEOL JSM 6060 and FEI NOVA NANOSEM 650 to investigate the microstructural evolution of the SB and experimental brick bodies. Quantitative elemental analyses were carried out on selected SEM areas by EDX.

Polished cross sections were produced by mounting sample fragments in low viscosity epoxy resin and polishing to a $1 \mu \mathrm{m}$ finish. Samples were coated with a thin layer of Pt prior to SEM imaging.

The colorimetric analyses of the experimental bricks were carried out at Ege Seramik Inc using an Erichsen Spectromaster 565-D according to EN ISO 10545-16 [40].

\section{Kinetic leaching tests}

The fired brick samples were placed in distilled water at a solid/liquid ratio of $1 / 10$. The bricks were kept in water for $1 \mathrm{~h}, 1$ day, 1 week and 1 month to determine the amounts of metals leaching into solution. At the end of each immersion
Table 6 Physico-mechanical properties of SB fired at $920^{\circ} \mathrm{C}$

\begin{tabular}{lllllll}
\hline Sintering Temperature & SRAF $(\%)$ & CS $\left(\mathrm{kg} / \mathrm{cm}^{2}\right)$ & WA $(\%)$ & L & a & b \\
\hline $920{ }^{\circ} \mathrm{C}$ & 0.20 & 88 & 16.77 & 60.42 & 17.26 & 26.76 \\
\hline
\end{tabular}


Table 7 Physico-mechanical properties of bricks containing maximum amount of waste fired at $800{ }^{\circ} \mathrm{C}$

\begin{tabular}{lllll}
\hline Brick composition & CS $\left(\mathrm{kgf} / \mathrm{cm}^{2}\right)(\cong)$ & WA $(\%)$ & SRAF $(\%)$ & Change in colour \\
\hline A & 80 & 15 & -0.04 & Negligible \\
B & 82 & 16 & -0.1 & Negligible \\
C & 74 & 17 & -0.12 & Negligible \\
D & 84 & 16 & -0.08 & Negligible \\
\hline
\end{tabular}

period, solution samples withdrawn were filtered using $0.45 \mu \mathrm{m}$ membrane filters and analysed by inductively coupled plasma mass spectrometry (ICP-MS Agilent 7500).

\section{Results and discussion}

\section{Production of the TWW sediment}

\section{Sedimentation of TWW in the presence of clinoptiolite}

The settling experiments were conducted at different concentrations of clinoptiolite and presented in Fig. 2a. It was seen that the rate of settling was quick in the first $15 \mathrm{~min}$ and then it slowed down and stopped after $60 \mathrm{~min}$. This was expected due to the presence of ionic species in the suspension of TWW. As it is known, the negative charge of clinoptiolite at this high $\mathrm{pH}$ (9.5) will be depressed by the presence of ions. Therefore, the clinoptiolite particles with no charge will come together to agglomerate due to van der Waals forces and settle quickly because of larger size of agglomerates (Fig. 2b). The settling rates were calculated through the slopes of the straight lines from Fig. 2a where rapid settling occurred. They were found to be $3.7,4.9,4.7$ and $4.4 \mathrm{~cm} / \mathrm{min}$ for $10,20,30$ and $40 \mathrm{~g} / \mathrm{L}$ clinoptiolite concentrations, respectively. The fastest settling rate of $4.9 \mathrm{~cm} / \mathrm{min}$ was attained at $20 \mathrm{~g} / \mathrm{L}$ clinoptiolite concentration. Therefore, $20 \mathrm{~g} / \mathrm{L}$ clinoptiolite content was determined to be the optimum clinoptiolite amount in this study.

Turbidity measurements were conducted using the supernatant obtained above the sediment to test the flocculation performance. The results were presented in Fig. 3a. As seen, the turbidity values decreased from 3300 NTU's to 600 NTU's which was not enough. Ideally, a well-flocculated suspension should settle leaving no suspended solids in the supernatant liquid and, hence, have a very low turbidity.

The effect of $\mathrm{pH}$ on FSV was determined and presented in Fig. 3b. As it is seen, there was no trend and the FSV values changed approximately between 35 and $60 \mathrm{~cm}^{3}$. There are some changes but these could be due to other reasons than surface charge of clinoptiolite. As discussed above, the electrical double layer around the clinoptiolite surface was expected to be depressed due to the high ion concentration of TWW. Therefore, the settling behaviour of clinoptiolite particles was not expected to change. The effect of a mixing rate on FSV
Fig. 9 SEM image and area EDX spectrum-elemental distribution of SB fired at $920^{\circ} \mathrm{C}$

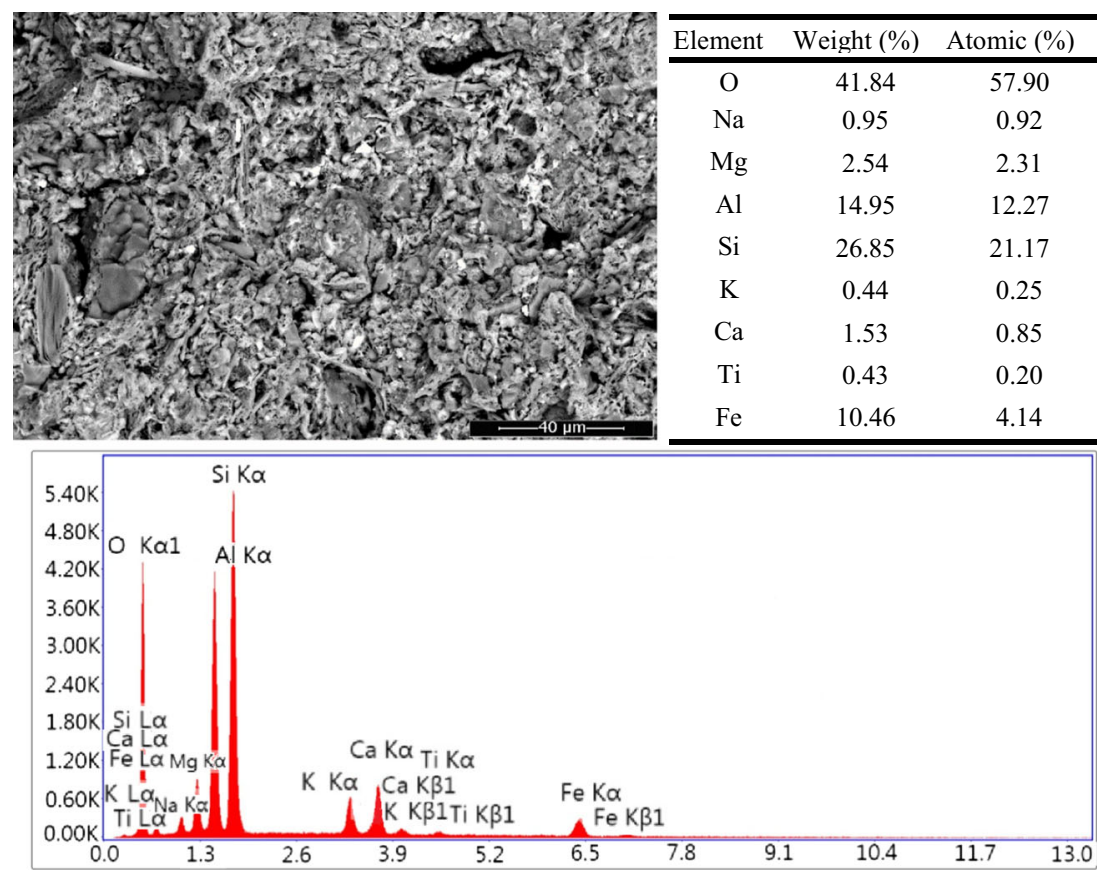


Fig. 10 XRD spectrum of SB fired at $920^{\circ} \mathrm{C}$

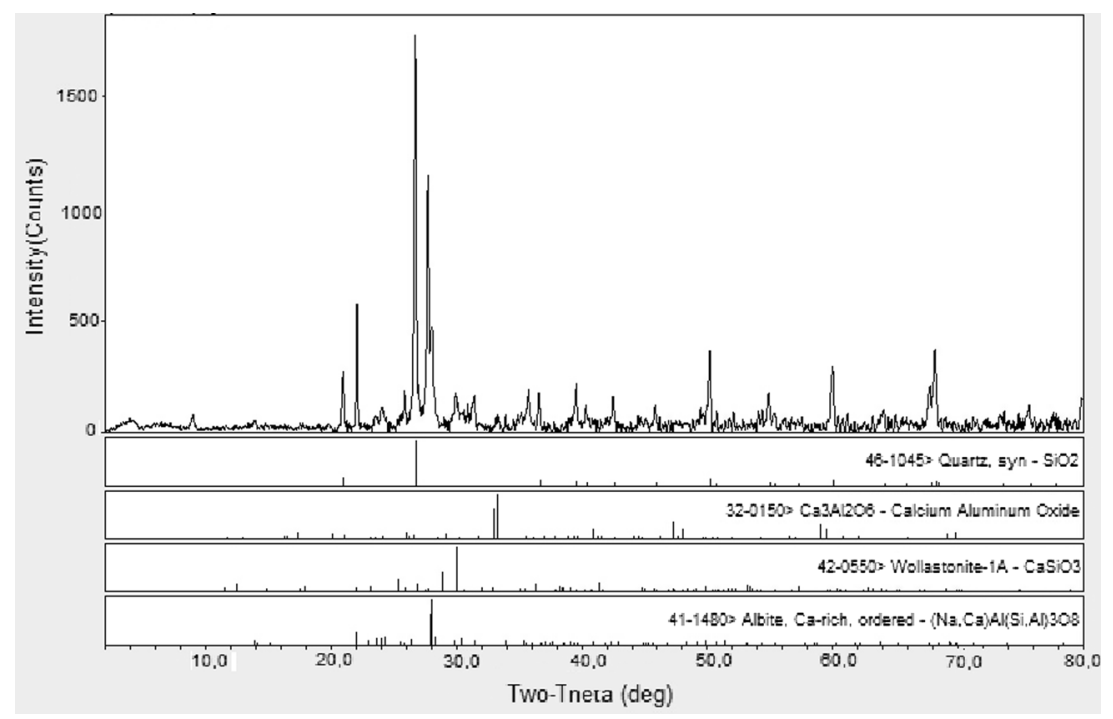

was also tested and found to be negligible, which was expected due to the steady state conditions of the system. In other words, the conditions of the solution and the surfaces did not change with an increasing mixing rate.

\section{Sedimentation of TWW in the presence of clinoptiolite and flocculants}

In this part of the study, the effect of flocculant type and concentration on FSV and turbidity of supernatant liquid was studied using the selected conditions and presented in Fig. 4a, b. As seen from the figures, the FSV values changed approximately between 38 and $78 \mathrm{~cm}^{3}$ while the turbidity values changed between 0 and 900 NTU. It was observed that these changes depended on the charge and size (molecular weight) of the flocculants used. Among the anionic polymers, the lowest FSV value was obtained with the anionic flocculant that had the highest molecular weight (PAM 4046). The effect of concentration, on the other hand, was not significant. FSV values of anionic polymers increased with decreasing molecular weight (Fig. 4a). On the other hand, the turbidity values of anionic flocculants were high and increased with an increase in molecular weight (Fig. 4b). The cationic flocculant PAM K6645 seemed to be the best coagulant aid for cheap clinoptiolite among the others to sediment the particles with a lowest turbidity value of almost zero (Fig. 4b) and showed
Fig. 11 SEM image and area EDX spectrum-elemental distribution of $\mathrm{D}$ brick containing $10 \mathrm{wt} \%$ solid leather waste and $5 \mathrm{wt} \%$ clinoptiolite fired at $800^{\circ} \mathrm{C}$

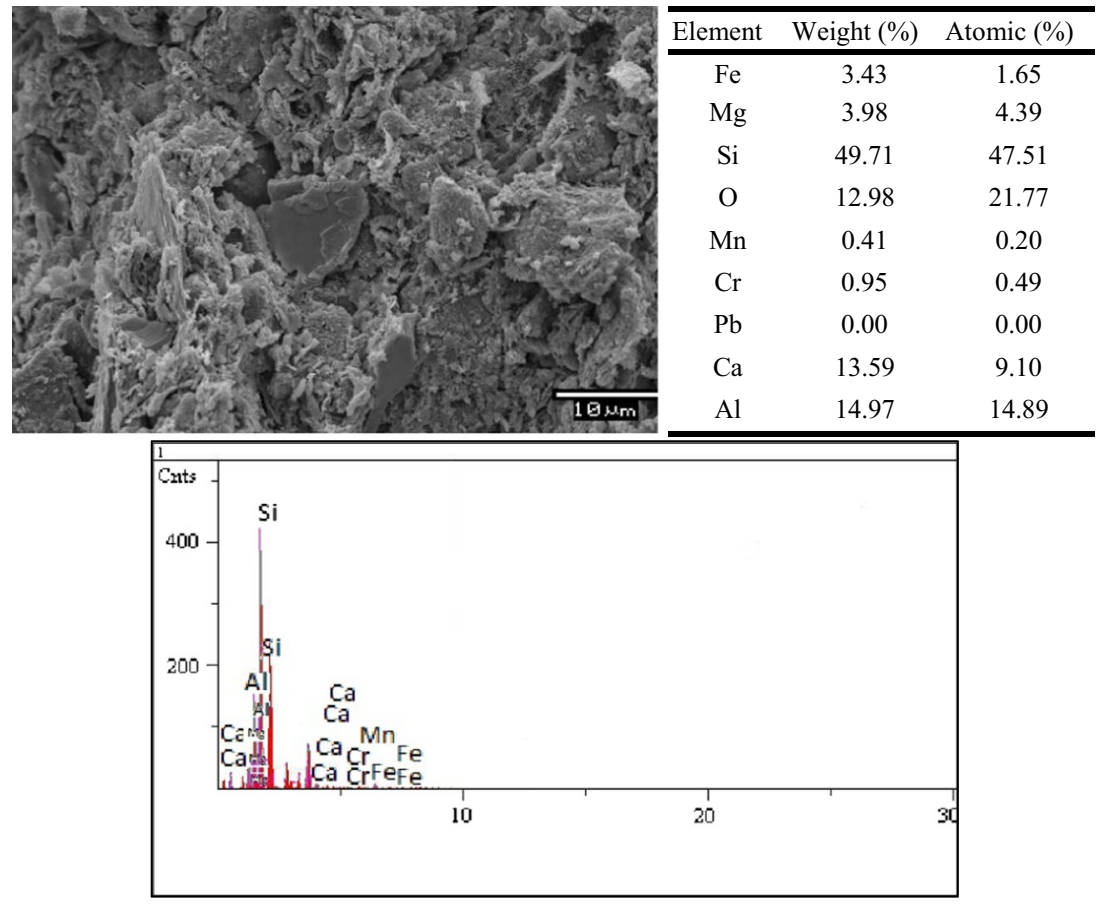


Fig. 12 XRD spectrum of D brick containing $10 \mathrm{wt} \%$ solid leather waste and $5 \mathrm{wt} \%$ clinoptiolite fired at $800{ }^{\circ} \mathrm{C}$
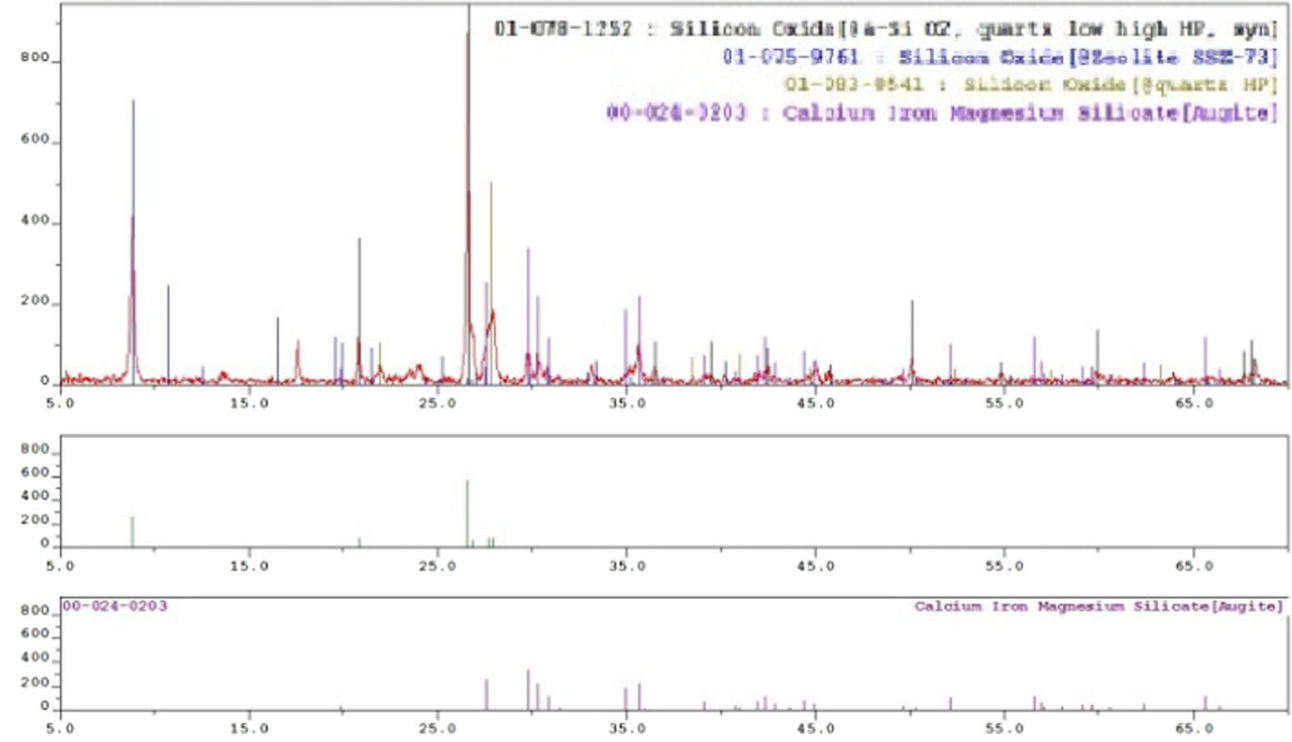

an excellent flocculation performance even in starving quantities. However, its FSV value was the highest. This might be due to the high molecular weight and cationic charge of molecules. The flocculant adsorbs onto surfaces of clinoptiolite due to its negative charge at this $\mathrm{pH}$, and particles settle due to bridging mechanism. Therefore, there might be space between particles due to the flocculant molecule between them. This will increase the sediment height. The decrease in the turbidity was also expected in this case. In the case of the non-ionic polymer (PAM N134), the supernatant liquid was not very clear (Fig. 4b) and the sediment height was the second highest (Fig. 4a). This might be again due to the presence of flocculants between the particles since they do not have any charge. In the case of anionic ones, no adsorption on surfaces was expected due to the similar charge (negative charge) of flocculants and clinoptiolite surfaces.

Cationic polyelectrolytes might be thought to be more suitable for flocculation. However, this may not be viable in terms of bridge formation. To build bridges among the solid particles, the polymer must get adsorbed strongly on the mineral particle surface. The adsorption capability improves with chemicals showing good adsorption properties such as amide groups. Whether cationic or anionic, the bridging capability enhances with increasing molecular weight.
Polymer adsorption and flocculation take place through a number of stages such as the mobilization of the polymer molecules with suspended particles following the initial adsorption of the polymer chain and its rearrangement which results in the final arrangement. Flocculation by poly acrylamides is considered to take place through the mechanism of the formation of the polymer bridge. According to this mechanism, the polymer adsorbs on the solid particle surface from several points owing to its high molecular weight.

\section{Encapsulation of TWW sediment in brick structure}

The purpose of this study was to encapsulate the sediment obtained from TWW in the structure of construction bricks. WA, CS, SRAF and colouring parameters were tested with experimental bricks with and without the additives under several conditions. The results of these studies were presented in Figs. 5, 6, 7 and 8. It can be seen from the figures that the effect of sediment on the brick structure changed depending on the firing temperature and the type/concentration of additives. It seems that the presence of clinoptiolite does not affect the brick properties negatively or positively under any conditions. The presence of leather waste on the other hand showed positive changes in the brick properties such as clinoptiolite at

Table 8 Results of kinetic leaching tests of bricks

\begin{tabular}{lclllllllll}
\hline Time & $\mathrm{Na}(\mathrm{mg} / \mathrm{L})$ & $\mathrm{K}(\mathrm{mg} / \mathrm{L})$ & $\mathrm{Mg}(\mathrm{mg} / \mathrm{L})$ & $\mathrm{Ca}(\mathrm{mg} / \mathrm{L})$ & $\mathrm{Au}(\mu \mathrm{g} / \mathrm{L})$ & $\mathrm{Zn}(\mu \mathrm{g} / \mathrm{L})$ & $\mathrm{Cr}(\mu \mathrm{g} / \mathrm{L})$ & $\mathrm{Ni}(\mu \mathrm{g} / \mathrm{L})$ & $\mathrm{Ag}(\mu \mathrm{g} / \mathrm{L})$ & $\mathrm{Al}(\mu \mathrm{g} / \mathrm{L})$ \\
\hline $1 \mathrm{~h}$ & 1.60 & 0.308 & 0.203 & 1.36 & 11.0 & 195 & 0.121 & 1.94 & 0.057 \\
1 day & 1.60 & 0.241 & 0.236 & 1.50 & 5.10 & 204 & 0.185 & 2.41 & 0.012 \\
1 week & 4.94 & 12.4 & 1.09 & 7.44 & 5.71 & 45.3 & 40.63 & 1.62 & $\mathrm{ND}$ & 14.9 \\
1 month & 12.0 & 11.6 & 1.80 & 11.0 & 7.11 & 8.84 & 42.02 & 1.26 & $\mathrm{ND}$ & 46.0 \\
\hline
\end{tabular}

$N D$ not detectable 
Table 9 Limiting values set by the Environmental Regulations for wastewater (Water Contamination Control Regulations, Turkish Ministry of Environment and Forestry, Published in Turkish State Newspaper (Resmi Gazete), December 31, 2004, No. 25687, www.resmi-gazete.org.) for those metals which were detected by ICP-MS to be over $10 \mathrm{ppb}$ in leach solutions

\begin{tabular}{llll}
\hline Heavy metals & Allowable limit (ppm) & Alkaline earth metals & Allowable limit (ppm) \\
\hline $\mathrm{Cr}$ & 2 & $\mathrm{Ca}$ & $\mathrm{NL}$ \\
$\mathrm{Ni}$ & 5 & $\mathrm{Na}$ & $\mathrm{NL}$ \\
$\mathrm{Zn}$ & $3-5$ & $\mathrm{~K}$ & $\mathrm{NL}$ \\
$\mathrm{Ag}$ & $1-5$ & $\mathrm{Mg}$ & $\mathrm{NL}$ \\
$\mathrm{Fe}$ & $3-10$ & & \\
$\mathrm{Al}$ & 3 & $\mathrm{pH}$ & $6-9$ \\
$\mathrm{Au}$ & & $\mathrm{pH}$ & \\
\hline
\end{tabular}

$N L$ no limit set by the regulations.

low concentration when compared to those of SB compositions (Table 6) fired at each experimental temperature.

All the values of WA capacity and of SRAF for the bricks containing either clinoptiolite/leader waste or both of them were in conformity with related brick standards $[37,39]$ for all conditions and compositions which is desirable as far as brick quality is concerned.

As seen from Figs. 5, 6, 7 and 8, no substantial variation in colouring parameters of bricks, due to the firing temperature and the type/concentration of additives, was observed. Furthermore, no substantial differences among the colouring parameters (L, a and b) of SB and experimental bricks occurred, either (Figs. 5, 6, 7, 8 and Table 6). In measuring the values of the chromatic coordinates (L, a and b), whiteness index was denoted as L, variations between green and red colours was denoted as a and variations between blue and yellow colours was denoted as $b$ [41, 42].

In Table 7, the physical properties of bricks containing maximum amount of waste fired at $800{ }^{\circ} \mathrm{C}$ was given. The criteria adopted for determining the optimal brick composition was to employ the maximum waste usage and the lowest sintering temperature in terms of environmental concerns and economy, respectively. Therefore, the optimal brick composition was determined to be the $\mathrm{D}$ brick fired at $800{ }^{\circ} \mathrm{C}$ containing $10 \mathrm{wt} \%$ solid leather waste and $5 \mathrm{wt} \%$ clinoptiolite already used as an aid for sedimentation. In this case, the CS, $\mathrm{WA}$ and SRAF values were, respectively, $84 \mathrm{kgf} / \mathrm{cm}^{2}, 16 \%$ and $-0.08 \%$, which were in good agreement with the related brick standards [37-39].

Figure 9 shows the SEM image and area EDX spectrumelemental distribution of SB fired at $920{ }^{\circ} \mathrm{C}$. The XRD spectrum of SB fired at $920 \mathrm{C}$ was given in Fig. 10. The major phases were quartz, albite, calcium aluminium oxide and wollastonite. Figure 11 shows the SEM image and area EDX spectrum-elemental distribution of $\mathrm{D}$ brick containing $10 \mathrm{wt} \%$ solid leather waste and $5 \mathrm{wt} \%$ clinoptiolite fired at $800{ }^{\circ} \mathrm{C}$ (optimal brick). Its XRD spectrum was given in Fig. 12. The major phases were designated as quartz and calcium iron magnesium silicate. As seen from the figures, both bricks represented similar porous microstructures which were supported by similar WA values of the SB (Table 6) and the optimal brick (Fig. 8).

\section{Leaching behaviour of fired bricks}

Leaching tests were carried out with the bricks produced to determine the amount of metal leaching from the fired samples. The results of the leaching tests are summarized in Table 8.

The ICP-MS analyses of the leach solutions from the brick type D (containing 10\% solid residue and 5\% clinoptiolite fired at $800{ }^{\circ} \mathrm{C}$ ) showed that concentrations of metals (such as $\mathrm{Cr}, \mathrm{Zn}, \mathrm{Ni}, \mathrm{Ag}, \mathrm{Al}$ ) in the leach solutions were always in ppb levels after the 1-month leach period (Table 8). Hence, only those elements which gave readings in ppm levels were $\mathrm{Ca}, \mathrm{Mg}, \mathrm{K}$ and $\mathrm{Na}$ (as alkaline earth metals) (Table 8). Based on these results, it is clear that metal released into solution from the brick (which contain both the clinoptiolite and waste additive or solid residue) is always lower than the permissible values (even less than the SB in several instances) (Table 9) most probably due to fixation reactions developing between the wastewater, clinoptiolite and the brick structure.

\section{Conclusions}

In this study, the harmful content of TWW was sedimented using clinoptiolite together with several types of anionic, cationic and non-ionic flocculants with different molecular weights and charge densities. The sediment obtained was then encapsulated in a brick structure to stabilize the sediment in the brick structure. The bricks manufactured were no risk to the environment and satisfied the relevant brick standards while lowering the sintering temperature from $920^{\circ} \mathrm{C}(\mathrm{SB})$ to $800^{\circ} \mathrm{C}$ which would lead to a substantial amount of energy saving. In addition, to use cheap and largely available 
clinoptiolite as a coagulant aid instead of conventional coagulants such as metal salts would be an advantage from an economical point of view. Besides, the use of valuable clay deposits in brick making would be reduced mitigating the negative impact of mining activities.

The following specific conclusions were drawn from this study:

- The fastest settling rate of $4.9 \mathrm{~cm} / \mathrm{min}$ was attained at a clinoptiolite concentration of $20 \mathrm{~g} / \mathrm{L}$ and the effect of $\mathrm{pH}$ and mixing rate on the sediment height (FSV) were found to be negligible.

- The cationic flocculant, PAM K6645, seemed to be the best to settle the particles with a lowest turbidity value of almost zero. However, FSV was high in the case of this surfactant. The supernatant liquid was not very clear, and the sediment height was high in the case of a non-ionic polymer (N134).

- The effect of sediment on the brick structure changed depending on the firing temperature and the type/ concentration of additives.

- The addition of clinoptiolite did not affect the brick properties negatively or positively under any conditions while the addition of leather waste showed positive changes for some conditions.

- The optimal brick composition was determined to be the D brick fired at $800{ }^{\circ} \mathrm{C}$ containing $10 \mathrm{wt} \%$ solid leather waste and $5 \mathrm{wt} \%$ clinoptiolite.

- The CS, WA and SRAF values of the optimal brick were $84 \mathrm{kgf} / \mathrm{cm}^{2}, 16 \%$ and $-0.08 \%$, which were in good agreement with the related brick standards.

- The sintering temperature was lowered from 920 down to $800^{\circ} \mathrm{C}$.

- After 1 month of leaching, the metal (Cr, $\mathrm{Zn}, \mathrm{Ni}, \mathrm{Ag}, \mathrm{Al})$ concentration released into solution from the optimal brick, which contained both the clinoptiolite (5\%) and waste additive ( $10 \%$ of SR) fired at $800{ }^{\circ} \mathrm{C}$, was always lower than the permissible values and even less than the $\mathrm{SB}$ in several instances.

Acknowledgements This research did not receive any specific grant from funding agencies in the public, commercial or not-for-profit sectors.

\section{References}

1. WORLD BANK GROUP: Tanning and leather finishing, pollution prevention and abatement handbook, effective (1998)

2. Ayalew, A.: Cleaner production options for solid waste management in the leather industry. M.Sc. Thesis, Addis Ababa University, Addis Ababa (2005)

3. Abreu, M.A., Toffoli, S.M.: Characterization of a chromium-rich tannery waste and its potential use in ceramics. Ceram Int. 35, 2225-2234 (2009)
4. Ozgunay, H., Colak, S., Mutlu, M.M., Akyuz, F.: Characterization of leather industry wastes. Polish J of Environ Stud. 16, 867-873 (2007)

5. Kolomaznik, K., Barinova, M., Vaskova, H.: Chromium VI issue in leather waste - a technology for the processing of used leather goods and potential of Raman spectroscopy in chromium traces detection. MACOS. 6, 447-455 (2012)

6. Wang, Y.S., Pan, Z.Y., Lang, J.M., Xu, J.M., Zheng, Y.G.: Bioleaching of chromium from tannery sludge by indigenous Acidithiobacillus thiooxidans. doi:10.1016/j.jhazmat.2007.01.005

7. Sharaf, S.A.A., Gasmeleed, G.A., Musa, A.E.: Extraction of chromium six from chrome shavings. JFPI. 2, 21-26 (2013)

8. Fernandes, H.R., Ferreira, J.M.F.: Recycling of chromium-rich leather ashes in porcelain tiles production. J Eur Cer Soc. 27, 4657-4663 (2007)

9. Swarnalatha, S., Srinivasulu, T., Srimurali, M., Sekaran, G.: Safe disposal of toxic chrome buffing dust generated from leather industries. J Hazard Mater. 150, 290-299 (2008)

10. Sekaran, G., Shanmugasundaram, K., Mariappan, M.: Characterization and utilization of buffing dust generated by the leather industry. J Hazard Mater. B63, 53-68 (1998)

11. Sekaran, G., Swarnalatha, S., Srinivasulu, T.: Solid waste management in leather sector. IJDMT. 1, 47-52 (2007)

12. Kanaragaj, J., Velappan, K.C., Chandra Babu, N.K., Sadulla, S.: Solid waste generation in the leather industry and its utilization for cleaner environment - a review. J Sci Ind Res. 65, 541-548 (2006)

13. Paul, H., Antunes, A.P.M., Covington, A.D., Evans, P., Phillips, P.S.: Utilising tannery waste as a protein source for poultry feed. In: Towards zero solid waste: Proceedings of $28^{\text {th }}$ International Conference on Solid Waste Technology and Management, Philadelphia, PA, USA. The Journal of Solid Waste Technology and Management, 10-13. (2013). ISSN 1091-8043

14. Famielec, S., Wieczorec-Ciurowa, K.: Waste from leather industry - threats to the environment. CzT. 1-Ch, $43-48$ (2011)

15. Sreeram, K.J., Ramasami, T.: Sustaining tanning process through conservation, recovery and better utilization of chromium. Resour Conserv Recy. 38, 185-212 (2003)

16. de Souza e Silva, P.T., de Mello, N.T., Menezes Duarte, M.M., Conceiçao, M., Montenegro, B.S.M., Araujo, A.N., de Barros Neto, B., Lins da Silva, V.: Extraction and recovery of chromium from electroplating sludge. J Hazard Mater. B128, 39-43 (2006)

17. Kurniawan, T.A., Chan, G.Y.S., Loa, W.-H., Babel, S.: Physicochemical treatment techniques for wastewater laden with heavy metals. Chem Eng J. 118, 83-98 (2006)

18. Haydar, S., Aziz, J.A.: Characterization and treatability studies of tannery wastewater using chemically enhanced primary treatment (CEPT) - a case study of Siddiq leather works. J Hazard Mater. 163, 1076-1083 (2008). doi:10.1016/j.jhazmat.2008.07.074

19. Song, Z., Willians, C.J., Edyvean, R.G.J.: Treatment of tannery wastewater by chemical coagulation. Desalination. 164, 249-259 (2004)

20. Haydar, S., Aziz, J.A.: Coagulation-flocculation studies of tannery wastewater using combination of alum with cationic and anionic polymers. J Hazard Mater. 168, 1035-1040 (2009)

21. Zhao, Y.Q., Bache, D.H.: Integrated effects of applied pressure, time, and polymer doses on alum sludge dewatering behaviour. Waste Manag. 22, 813-819 (2002)

22. Zeng, Y., Yang, C., Zhang, J., Pu, W.: Feasibility investigation of oily wastewater treatment by combination of zinc and PAM in coagulation/flocculation. J Hazard Mater. 147, 991-996 (2007)

23. Fu, F., Wang, Q.: Removal of heavy metal ions from wastewaters: a review. J Environ Manag. 92, 407-418 (2011)

24. Ibrahimi, M.M., Sayyadi, A.S.: Application of natural and modified zeolites in removing heavy metal cations from aqueous media: an 
overview of including parameters affecting the process. Int J Geo Earth Env Sc. 3, 1-7 (2015) ISSN: 2348-0254

25. Golomeova, M., Zendelska, A., Blazev, K., Krstev, B., Golomeov, B.: Removal of heavy metals from aqueous solution using clinoptilolite and stilbite. IJERT. 3, 1029-1035 (2014) ISSN: 2278-0181

26. Hansson, A.: Mechanism of zeolite activity in biogas co-digestion. M.Sc. Thesis, Department of Physics, Chemistry and Biology, Institue of Technology, Linköping University, Sweden (2011)

27. Gorimbo, Joshua: Effect of the homoionic form of clinoptilolite on $\mathrm{Ni}^{2+}$ adsorption isotherms: a thermodynamic study. M.Sc. Thesis, University of the Witwatersrand, Johannesburg (2011)

28. http://www.geo.wvu.edu/ lang/Geol484/Zeolites.pdf (2016). Accessed 17.10.16

29. Halimoon, N., Yin, R.G.S.: Removal of heavy metals from textile wastewater using zeolite. Environment Asia. 3, 124-130 (2010)

30. Koprivanac, N., Cerjan-Stefanović, Š., Papić, S., Meteš, A., Kušić, H.: Removal of the $\mathrm{Cu}$ (II) complex dyes from wastewater with natural zeolite. In: Zeolite '02 (6th International Conference on the Occurrence, Properties and Utilization of Natural Zeolites), Tessaloniki, Greece, 3-7 June (2002)

31. Kanawade, S.M.: Removal of heavy metals from wastewater by using natural zeolites as adsorbent. IJESTA. 01, 30-38 (2015)

32. Erdem, E., Karapinar, N., Donat, R.: The removal of heavy metal cations by natural zeolites. J Colloid Interface Sci. 280, 309-314 (2004)

33. Shaheen, S.M., Derbalah, A.S., Moghanm, F.S.: Removal of heavy metals from aqueous solution by zeolite in competitive sorption system. IJESD. 3, (2012)
34. Zhang, P., Ding, W., Zhang, Y., Dai, K., Liu, W.: Heavy metal ions removal from water using modified zeolite. J Chem Pharm Res. 6, 507-514 (2014)

35. Khachatryan, Sh.V.: Heavy metal adsorption by armenian natural zeolite from natural aqueous solutions. In: Proceedings of the Yerevan State University, Chemistry and Biology, № 2, 31-35, (2014)

36. Motsi, T., Rowson, N.A., Simmons, M.J.H.: Kinetic studies of the removal of heavy metals from acid mine drainage by natural zeolite. Int J Miner Process. 101, 42-49 (2011)

37. TS EN 771-1:2011+A1: Specification for masonry units - Part 1: clay masonry units Turkish Standards Institute, Ankara, Turkey (2015)

38. TSE 4790: Turkish Standard Test Method for Common Bricks and Roofing Tile Clays. Turkish Standards Institute, Ankara (1986)

39. ASTM C67-92 a: Standard test methods of sampling and testing brick and structural clay tile. Philadelphia, USA: American Society of testing and materials 1916 Race street PA 191031187 (1992)

40. TS EN ISO 10545-16: Ceramic tiles-Part 16: determination of small colour differences, Turkey (2012)

41. Hunter, R.S., Harold, R.W.: The Measurement of Appearance, 2nd edn. John Wiley and Sons, Inc., New York (1987)

42. HunterLab: Hunter L, a, b color scale. Insight on Color. 8, 1-4 (2008) downloaded from http://www.hunterlab.com/appnotes/ an08_96a.pdf 